\title{
Changes in travel time and the load of road network, depending on the diversification of working hours: case study the tódź Voivodeship, Poland
}

\author{
MARTA BOROWSKA-STEFAŃSKA, MICHAŁ KOWALSKI, SZYMON WIŚNIEWSKI
}

University of Lodz, Faculty of Geographical Sciences, Institute of the Built Environment and Spatial Policy, Lodz, Poland; e-mail: marta.borowska@geo.uni.lodz.pl, michal.kowalski@geo. uni.lodz.pl, szymon.wisniewski@geo.uni.lodz.pl

ABSTRACT This article has two major goals - a methodological and a research one. The former is the development of a method enabling the prediction of the load of the road network, while the latter focuses on determining the influence commuting has on the load of the road network and changes in travel time within the Łódź Voivodeship. For the purposes of this study proprietary we used software based on a greedy algorithm. The applied method in combination with the proprietary software returns good results when directions of traffic flows are under scrutiny. The assumptions made herein do simplify reality, a simplification which stems from the quality of the available data and the calculating capacity of computers. On the other hand, the research goal has only been partially reached with regard to the method applied in the article.

KEY WORDS transport geography - daily mobility - commuting to work - congestion - individual transport - Łódź voivodeship - Poland

BOROWSKA-STEFAŃSKA, M., KOWALSKI, M., WIŚNIEWSKI, S. (2020): Changes in travel time and the load of road network, depending on the diversification of working hours: case study the Łódź Voivodeship, Poland. Geografie, 125, 2, 211-241.

https://doi.org/10.37040/geografie2020125020211

Received August 2018, accepted January 2020.

CC Česká geografická společnost, z. s., 2020 


\section{Introduction}

Currently, numerous metropolises face challenges related to the mitigation of the negative effects of human activity, including those directly connected with mobility through the use of cars (Rastogi 2011, Nosal 2011). This mode of road transport produces noise (Mayeres, Ochelen, Proost 1996) and pollutes the air (Palmgren et al. 1999), with large-scale movement of people resulting in congestion (Arnott, Rave, Schöb 2005), insufficient parking spaces (Topp 1993), and road accidents (Beckmann 2004). Morning congestion is one of the most serious challenges faced by big cities today, and therefore, it is crucial to research the matter in order to find ways to partially relieve the load on the road network, especially during rush hours, and in consequence, to mitigate the negative effects of this phenomenon for both people and the natural environment. The morning commute issue has been thoroughly researched in the literature since the late 1960's, when Vickrey (1969) published his classic bottleneck model. Research focuses on costs (Xiao, Qian, Zhang 2011), system optimization based on dynamic pricing strategy (Gonzales, Daganzo 2012), analysis of differences between morning and afternoon peaks (Gonzales, Daganzo 2013; Lamotte, Geroliminis 2018) and travel preferences towards risk and ambiguity ( $\mathrm{Liu}, \mathrm{Li}, \mathrm{Hu} 2018$ ). In the following years, there were numerous papers on the issue (Table 1).

A considerable amount of the literature is based on the assumption that travelers choose their departure time to minimize individual travel cost, which includes both travel time and scheduling in any delay. Analytical approaches are employed to obtain the travelers' equilibrium trip scheduling in the morning peak hours (Jia,

Table 1 - Selected research on bottleneck problem

\begin{tabular}{|c|c|}
\hline Authors & Research problem \\
\hline $\begin{array}{l}\text { Smith (1984) } \\
\text { Daganzo (1985) } \\
\text { Hendrickson, Kocur (1981) } \\
\text { Xiao, Qian, Zhang (2011) }\end{array}$ & Equilibrium pattern at a single bottleneck - morning travel \\
\hline $\begin{array}{l}\text { Arnott, De Palma, Lindsey (1990) } \\
\text { Liu, Nie (2011) }\end{array}$ & $\begin{array}{l}\text { Equilibrium pattern at a simple network of routes in parallel bottleneck - } \\
\text { morning travel }\end{array}$ \\
\hline De Palma, Lindsey (2002) & Asymmetry between morning and evening commutes \\
\hline De Palma, Lindsey (2004) & Congestion pricing, general-equilibrium welfare analysis \\
\hline Kwon, Mauch, Varaiya (2006) & $\begin{array}{l}\text { Congestion delay in a freeway section. Components: the delay caused by } \\
\text { incidents, special events, lane closures, and adverse weather; the potential } \\
\text { reduction in delay at bottlenecks that ideal ramp metering can achieve; and } \\
\text { the remaining delay, caused mainly by excess demand. }\end{array}$ \\
\hline Qian, Zhang (2011) & Multi-modal morning commute in a one-to-one corridor network \\
\hline
\end{tabular}


Wang, Cai 2016). The bottleneck model of the morning commute has been studied extensively for the case where all commuters are treated as being identical and wish to depart the bottleneck at a common time (Gonzales, Daganzo 2012).

This paper has two major goals - a (1) methodological and a (2) research one. The (1) former is to develop an approach which enables the prediction of the road network load, while the (2) latter is aimed at determining the impact of commuting on the load on the regional road network, travel times, and at analysing the scale of this impact with reference to the different hours at which employees start work. The paper focuses exclusively on commuter traffic, since this is one of the most frequent and regular forms of mobility. What is more, it also constitutes the most significant and visible manifestation of the functional and spatial relationships between various towns, cities, municipalities, districts and other types of regional units. Their analysis is absolutely crucial, not only in terms of scientific research itself, but also for spatial planning and administrative management at various levels of authority (Bartosiewicz 2012, Kraft 2014, Guzik 2015). Nowadays, large numbers of commuters travel to work, covering great distances on a daily basis, which is particularly noticeable in industrialised societies. Commuting can be achieved by car, motorbike, public transport, bicycle and on foot, and yet, it is the private car that has become the most frequently chosen mode of transport, which results in the morning and evening rush hours, and in increased travel time (Noland, Small 1995; Mauss, Jarczok, Fischer 2016). The existing studies that cover morning commuting focus mainly on individual trips, which inspired the authors of this paper to scrutinise the issue.

To the best of our knowledge, the problem discussed in this article is the first attempt to determine the road network load and travel times in the Eódź Voivodeship on the basis of data on commuting. This is carried out (with the authors' proprietary software) across different scenarios regarding departure time and arrival time for all network users. The remaining parts of the paper contain basic definitions used in the work, the theoretical foundations of the proposed modelling of the road network load, a brief description of the analysed area, and the results and conclusions, which also include further possible research areas using the application.

\section{Background}

'Mobility is not only understood to be the collection of journeys carried out during the course of a day, but as a reflection of the reasons for making such journeys. The way in which a person travels is directly related to their socioeconomic characteristics (gender, age, occupation, place of residence, etc.), and with the daily activities they perform (work, training, leisure, etc.), since travel is simply the 
means of access to any of these activities. Therefore, the study of mobility allows us to simultaneously observe the behaviour of different social groups, and is described in the literature as a reflection of social structure' (Olabarria et al. 2013, p. 434). This highlights how exceptionally important an issue within geographical studies (Coulter, Ham, Findlay 2016) it is in its very broad meaning.

Macroscale traffic modelling is performed on the basis of various methods. In the past, the most popular approaches included: the Fratar Method (Fratar 1954; Bartuška, Čejka, Caha 2015) and the Gravity Model (Voorhees 1955; Jung, Wang, Stanley 2008). Over time, other theories and methods were developed that enabled modelling with a greater number of variables (including modal division and more precise approaches to traffic distribution over the network, which could then be characterised by the capacity of its individual sections, the speed of free-flow traffic, temporal and financial costs, etc.). These theories have become the basis for a comprehensive approach to traffic modelling - the Four-Step Model (McNally 2000) - which is still eagerly applied today, though criticised almost as readily (e.g., Hayduk, Glaser 2000; Bollen 2000). Apart from this model, alternative approaches to traffic modelling and forecasting are being simultaneously developed, including the Post Processing and Direct Models (Cervero 2006), the Separate Factor Analysis Method, the Two-Step Procedure, the Jigsaw Piecewise Technique (Bollen 2000) and methods based on the Activity Approach (Multi-Agent Transport Simulation; Balmer et al. 2008; Horni, Nagel, Axhausen 2016).

When presenting only selected types of trips (a single-motivational approach), some researchers do not rely on models but on information resulting from actual measurements, which they then generalise from. It is the process of traffic distribution over the network that is actually being modelled there (BorowskaStefańska, Domagalski, Wiśniewski 2018; Rosik et al. 2018). This approach does not require complex procedures and, as long as the input data is reliable, it may be a valuable contribution to further analyses of traffic distribution over the network. Therefore, this is the approach that we have taken in this paper. Naturally, an optimum solution here would be the presentation of the trip generation model supported by agent-based modelling. However, given the limited data, the behavioural theories and models could be difficult to implement.

Traffic distribution modelling is based on various mathematical premises and formulas, which are usually constituents of the algorithms that describe the operation of applications aimed at supporting the research process. A review of the literature on such applications was conducted by Miller and Horowitz (2007). In general, the procedure for solving a transport issue is based on premises of graph theory (e.g., Bílý, Fiedler, Nožička 1958; Ford, Fulkerson 1956) and findings related to statistical or dynamical methods of traffic distribution over networks (Daganzo, Sheffi 1977; Han, Heydecker 2006). Even though graph theory dates back to 1741 (Derrible, Kennedy 2011), it was first applied to road transport systems in 
the late 1950s and remained popular until the 1970s. Bodino (1962), was the first to use graph theory in transport systems, and yet he did not take into account the network model (since his research was conducted before the era of computerisation; Derrible, Kennedy 2011). Initially, graph theory was used for the identification and description of the structure of transportation networks (Garrison 1960; Nystuen, Dacey 1961; Gould 1967). However, Ogunsanya and Ade (1986) indicated that graph theory could also be applied successfully in flow estimation of intraurban networks. Today, we observe a return to the application of graph theory in transport studies, which usually focus on the analysis of network robustness (Scott et al. 2006), and the impact of features of transportation networks on travel distance, trip assignment and even mode of choice (Parthasarathi, Hochmair, Levinson 2009). Parthasarathi, Hochmair and Levinson (2009) prepared a review of possible applications of graph theory in transport studies from the historical perspective. Our research also utilises a graph-based approach to the network structure, where individual intesections/transport regions have been presented as nodes, with roads between them as edges. Therefore, the analyses shown in this paper fit squarely into the stream of transport issues which involve the application of graph theory.

\section{Description of the researched area}

Within the Łódź Voivodeship, there is one large city, its capital - Łódź (population: 696,503, the Polish Central Statistical Office 2016), as well as 14 mid-sized towns (population: 20,000-100,000; Fig. 1), and 29 small towns (population: below 20,000). Eódź is the central city of the region, its largest job market and is home to administrative institutions and numerous service centres of regional importance, e.g., organisations related to education, healthcare, trade, culture and entertainment (Bartosiewicz, Pielesiak 2012). Within the borders of the Łódź Voivodship, 135,905 people commute to work (13.5\% of the employed; the total number of the employed in the voivodeship as of 2011 equals 1,011,636 - data provided by the Polish Central Statistical Office). Undoubtedly, the greatest direction of flow is towards the city of Łódź (approx. 36\% of all commuters; Fig. 1). As far as the volume of commuting employees is concerned, the largest values come from communities in the immediate vicinity of Łódź, e.g., Zgierz, Pabianice, and Aleksandrów Łódzki. It must be emphasised, however, that the bigger the centre, the higher the flows become (Bartosiewicz 2012).

The Łódź Voivodeship is located in the centre of Poland (the country's geographical centre lies only 23 kilometres to the north-east of the voivodeship capital), which proves to be very convenient for transport accessibility (Fig. 2). The majority of the most prominent metropolitan centres in Poland, including 


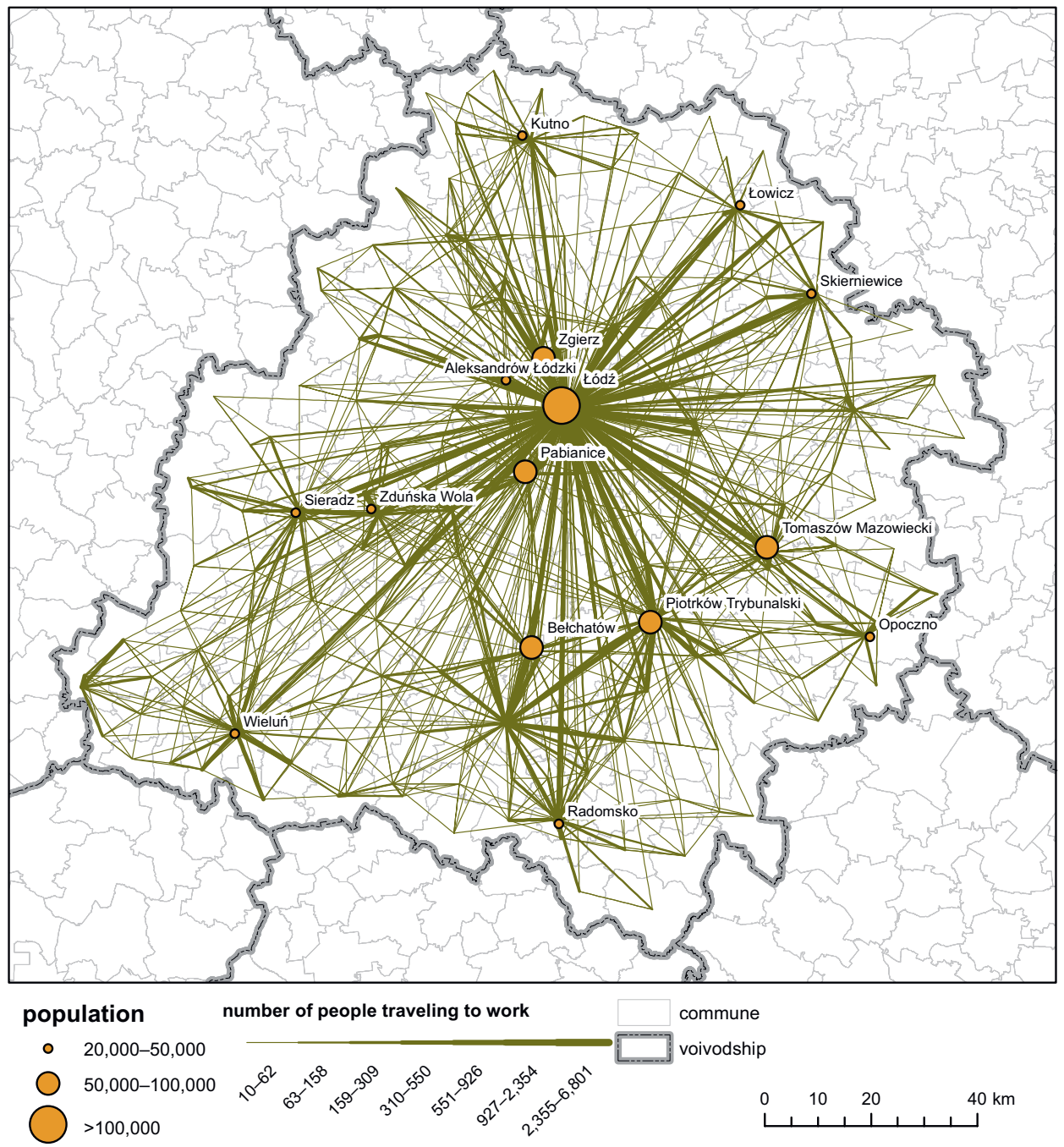

Fig. 1 - Commuting to work in the Łódź Voivodeship in 2011. Source: authors' own elaboration, based on the Polish Census of 2011.

9 voivodeship capitals, lie within the 200-kilometre equidistant line (physical distance) from Łódź (Wiśniewski 2015).

The following motorways run within the borders of the researched voivodeship: the A1 (from north to south: Gdańsk - Łódź - Gorzyczki - the border with Czechia) and the A2 (from west to east: the border with Germany - Świecko - Łódź - Warsaw - Kukuryki - the border with Belarus), with a total length of approx. 264 kilometres, together with expressways (177 km; Fig. 3). 


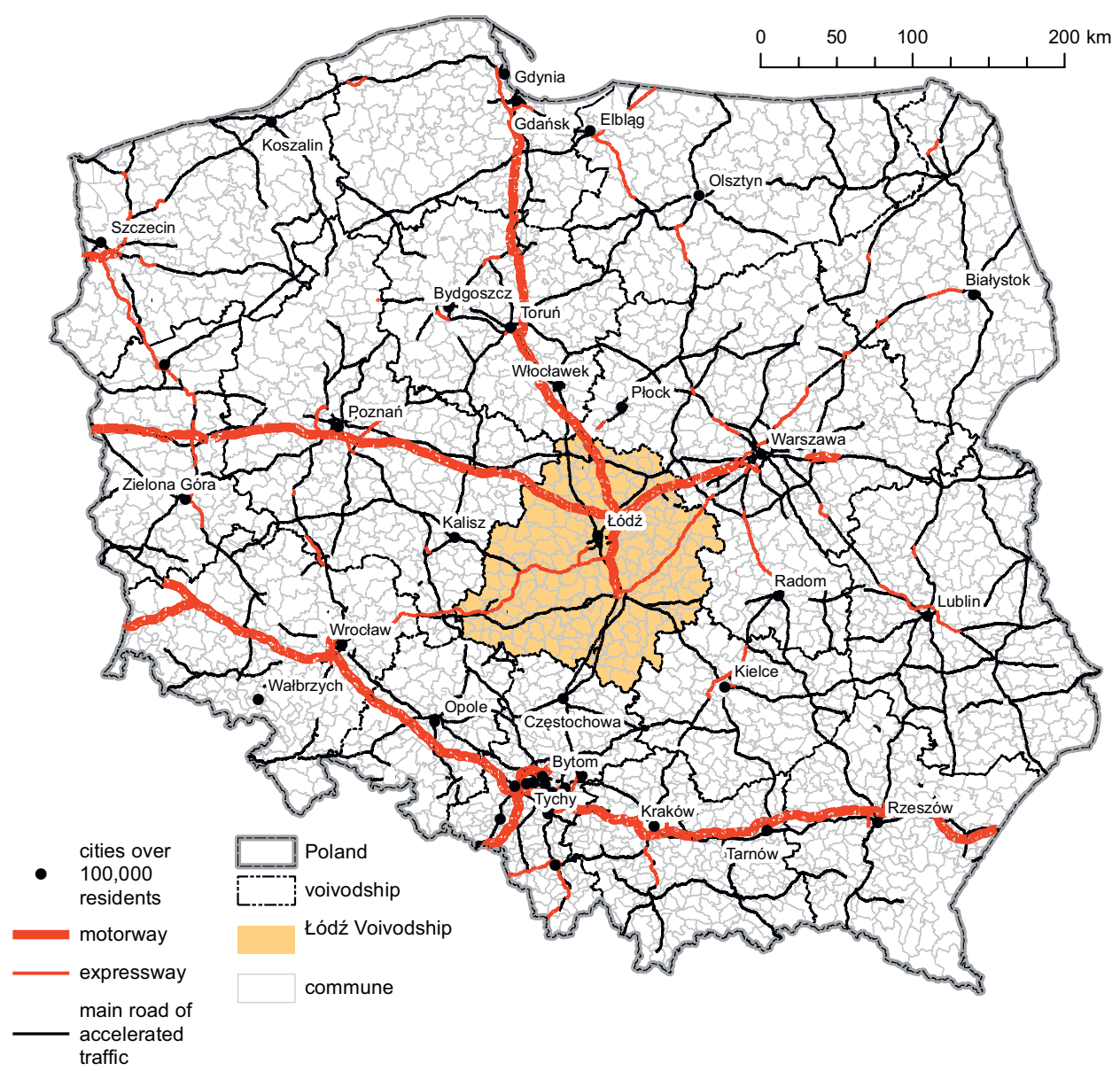

Fig. 2 - Location of the Łódź region. Source: authors' own elaboration.

According to CSO (2015), there were 1,314,000 cars registered in the Eódź Voivodeship (in the whole of Poland: 20 million), with the ratio of 525 registered cars per 1,000 people (the average in Poland: $520 / 1,000$ ). Each year, there are 817.6 million trips within the voivodeship, i.e., 411 trips per person, with 'return home' being the most common trip motivator $-49.6 \%$ of all trips, followed by commuting to work $-25.3 \%$ (Fig. 4 ).

The share of shopping-related trips amounts to $9.5 \%$, and the lowest percentage is attributed to journeys connected to holidaying (0.3\%). When 'return home' is removed from the total number of trips, the largest percentages are for commuting to work (50.3\%), shopping (18.9\%), or commuting to schools/universities and trips related to leisure activities, which account for $6.4 \%$ each. The aforementioned study 


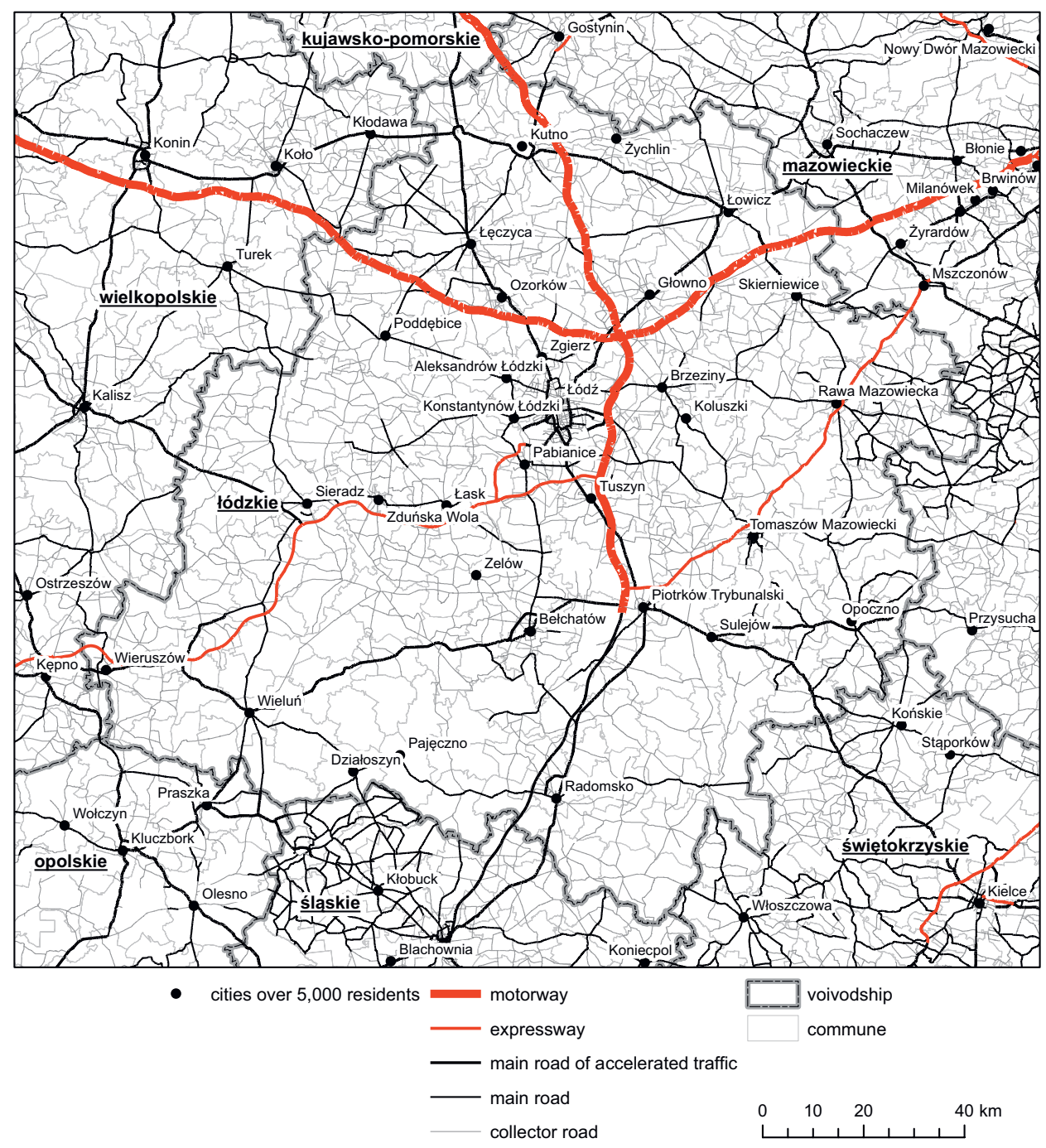

Fig. 3 - The road network of the Łódź Voivodeship. Source: authors' own elaboration.

also shows that the largest numbers of trips are taken on weekdays, from 6.00 to 7.59 a.m., i.e., $23.7 \%$ (more specifically: 6.00-6.59 a.m. - 10.6\%, and 7.00-7.59 a.m. $13.1 \%$ ), while the afternoon peak hours are from 2.00 to 3.59 p.m. (19.6\%), and from 4.00 to 5.59 p.m. (14.6\%). When it comes to modal classification, the majority of trips are conducted via means of motorised transport (77.1\%), while non-motorised transport (walking, cycling) accounts for $22.7 \%$. For motorised transport, the most preferred mode is the car (56.4\% passenger trips), while $20.1 \%$ passengers use public transport. In the Łódź Voivodeship, there is at least one car in $63.9 \%$ of 
a share of travel to work in general travel

share of respondents who use the car every day in commuting to work/school

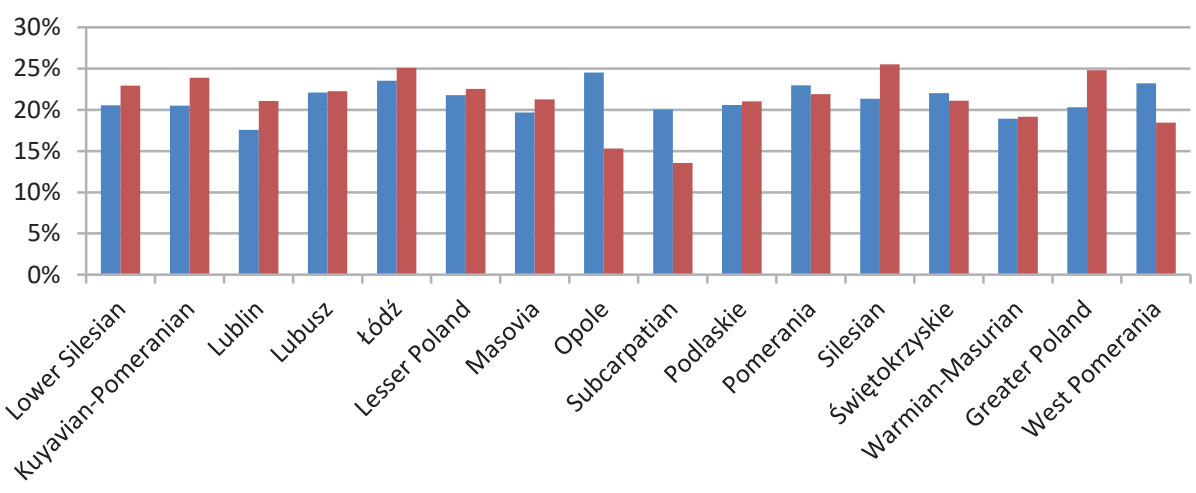

Fig. 4 - The share of commuting to work within the total number of trips, and the frequency of car use in trips to work/school - broken down into voivodeships in Poland. Source: CSO 2015.

households, and over $54.4 \%$ people use this means to commute to work, school or university. In Poland, nearly $64 \%$ of people commute to work by car (approx. 56\% drive themselves to work, while over $8 \%$ travel as passengers). Residents of the Łódź Voivodeship declare that the main reason why they choose the car over public transport when commuting to their workplaces or educational institutions is the excessive walking distance to the nearest stop or station, and the shortage of appropriate connections in the public transport timetable (The Pilot Study on People's Travel Behaviour in Poland, 2015). The data presented above reveal the impact of commuting to work and the use of private cars in Łódź Voivodeship, which is one of the key reasons for selecting the region for research. This is also confirmed from a European perspective, since intraregional comparative analyses show that the car-use rate for the Eódź Voivodeship noticeably exceeds the average ratio in the European Union (EU 28; Eurostat Regional Yearbook, 2018). When analysed from the Pan-European perspective, the issue of road transport and its functioning in the Łódź Voivodeship also appears to be a crucial problem with regards to the traffic-related death rate. While the average for the EU 28 group is 50 fatalities per one million residents, the number in the Eódź Voivodeship reaches 86 . Therefore, any study that may contribute to the improvement of traffic organisation seems to be justified. The functional and spatial structure of the Łódź Voivodeship was another argument which facilitated its adoption as the research territory. In many ways, the structure here reflects typical features of the whole country, since its regional settlement system is characterised by regular dispersion of towns and cities with a well-developed, multilevel hierarchical structure, where the hub city dominates other local centres. The distribution of cities in general, and of small 


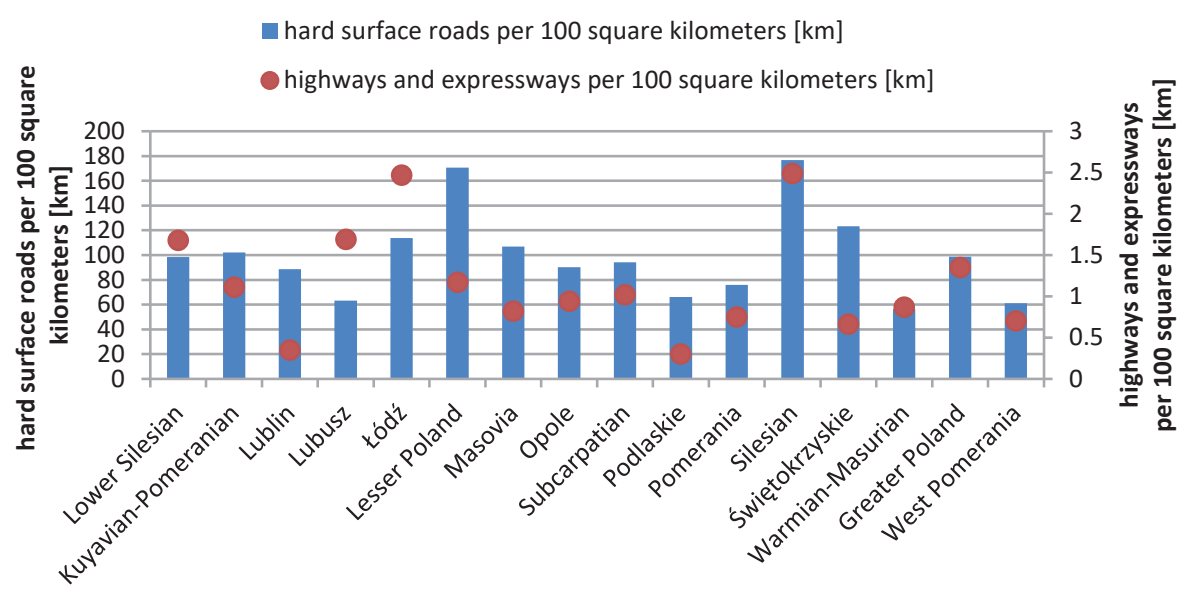

Fig. 5 - Density of hard-surfaced roads, motorways and expressways by voivodeship in Poland in 2017. Source: Local Data Bank, Central Statistical Office.

and medium-sized towns in particular, is uniform in space (The Concept to Spatial Planning and Development of Poland 2030). However, the Łódź Voivodeship is also a region with an extraordinary road infrastructure, including high-parameter routes (express and motorways; Fig. 5), which greatly facilitates the carrying out of simulations of the road network load and studies on the manner in which this load is then 'distributed' onto other road classes.

Another reason why the Łódź Voivodeship has become such an important research ground is the fact that the number of people who commute to workplaces within the region ( $6.1 \%$ of all commuters) is almost identical to the average ratio for all voivodeships in the country (6.2\%).

The final factor that contributed to the selection of the Eódź Voivodeship and its road network is the extremely dynamic traffic growth on the extra-urban network of trunk roads in recent years. The two latest general traffic measurements - conducted in Poland in 2010 and 2015 - show that the greatest increase in vehicle traffic among all regions of the country was recorded in the Łódź Voivodeship (the ratio of traffic changes between 2010 and 2015 amounts to 1.26, whereas the lowest value is 1.04 - for the Lublin Voivodeship and Świętokrzyskie Voivodeship, with Poland's average being 1.14; Opoczyński 2016).

\section{Research method}

The data on commuting to work within the Łódź Voivodeship was obtained from the National Population and Housing Census, with an accuracy to the smallest 
Polish administrative unit - the commune. In order to evaluate the data, the Polish Central Statistical Office used not only tax office registers (similarly to previous research of this type), but also data obtained from the resources belonging to other administrators, which allowed for a more accurate determination of commuter numbers (Krywult-Albańska 2012, Panecka-Niepsuj 2015).

The data on commuting to work - which are the source material incorporated into the study - are the only data of that type available for Poland (prepared by the Central Statistical Office and presenting situation as of 2011). The authors recognise that while it is not current, there is no other comprehensive data devoted to commuting to work in Poland. What must be emphasised, however, is the fact that the data is not current is of secondary importance for the purposes of the research objective herein, since it is its exhaustiveness that matters more. The Central Statistical Office provides data in the form of a table where subsequent rows contain information on the place of residence (municipality) and workplace (municipality), and the number of people to whom the data refers, facilitating the development of the structure of traffic that is generated by workplaces. The 2011 study on commuting to work for all employees was conducted on the basis of data recorded in administrative registers and obtained by the Public Statistical Office for the purposes of the National Census of Population and Housing 2011. The methodology for the study was developed on the basis of previous research carried out related to the implementation of The Survey of Employment-Related Population Movements in 2006. This time, however, the existing source of data ( $\operatorname{tax}$ registers) was enriched with resources from other authorities. The information retrieved from these sources made it possible to characterise commuters by gender and age, and above all, to identify more precisely the location of their workplace, which - in combination with their place of residence - allowed us to determine the directions of employment-related flows. On the basis of these registers alone, however, it is not possible to establish the mode of transport, travel frequency and duration for these commuters. The study on commuting to work showed that $3,136,000$ contracted employees commuted to work in 2011, which accounted for $32.5 \%$ of their total number. The aforementioned data, with the assumption that the phenomenon is evenly distributed across all communes of any given district, were compared to the car-use rate, which in Poland is aggregated to the level of district (level 2 of local self-governing bodies) district. Another premise was that the distribution of people owning a car corresponds with the distribution of car owners who commute to work outside the borders of any given commune. Next, the number of employees commuting to work was multiplied by the thus obtained car-use rate of the commune. In consequence, a slightly more detailed picture was gained, which included both everyday commuting and the number of vehicles that employees had at their disposal. However, attention should be paid to a simplification within this method, which stems from data imperfection. It is 
worth noticing that this fault may originate from the uneven distribution of the motorisation rate, both in terms of space (within the district) and structurally (among employees who commute to work outside the borders of the commune). It can be assumed that the number of vehicles for each resident commuting to their workplace outside the borders of the commune is higher than average. Until now, this phenomenon has not been fully researched empirically, due to the sensitivity of the data. Attempts made to estimate the available data in Poland it returned mixed results, which can chiefly be explained by the choice of transport accessibility via public modes of transport. Cities characterised by a broad spatial range of commuter isochrones for public transport usually report a lower share of commuters who use individual modes of transport. This stems from the fact that an efficiently working system of public transport is replaces individual car transit (Wiśniewski 2015). Estimates show that only $12 \%$ of employees from outside Warsaw commute to the Polish capital city by car, while this ratio grows to $55.4 \%$ for the regional centre Białystok. Interestingly, this ratio decreases with an increase in distance between employees' homes and workplaces (Rosik, Stępniak, Wiśniewski 2010).

In order to explain the analyses conducted in this article, one should also clarify the methods related to the way in which the workplace and the location of the homes of employees who commute there were determined, and the stipulation of the load of the road network and commute travel time. Due to the nature of the aggregation of the data related to commuting to work, it was assumed that the starting point and the destination of the trip is the centroid of the commune. Thus, all employees who commute to work by car outside their home commune start off at this point, heading towards the centroid of the commune where their workplace is located. The site of the point that incorporates the centroid of the commune into the road network was determined on the basis of its Euclidean distance to the nearest road node (interchange). In order to avoid mistakes related to the actual possibility of accessing the road network at this point, it was assumed that express and motorways are incorporated into the network only through actually existing entry ramps.

The applied tools for analysing interregional movements, i.e., the ones that focus, inter alia, on trips aggregated within the administrative boundaries of a given municipality or region pose a formidable challenge when attempting to determine the starting points and destinations for such trips. It was assumed that the starting point and the destination of a given trip are located within the node of the road network that is located at the closest Euclidean distance from the geometric centroid of the unit which is the starting point or the destination. The concept of centroid as such is commonly used in network studies at this territorial level, and the centroid itself is designated in various manners for example as geographical centroid (Linneker, Spence 1996) or population-weighted centroids 
(Stępniak, Jacobs-Crisioni 2017) and yet, this concept is not flawless in the presented method, which stems from two fundamental elements. The first, though slightly less important, one is the fact that starting a trip at a single spot leads to a considerable load on the edge (road) running from the starting point to subsequent nodes along the route. The application of such a method of designating starting points and destinations will result in even greater difficulties, due to the fact that the actual set of destinations is reduced to a single point. In studies focusing on analyses of arrival at a specific time, it leads to an extreme load on the edges adjacent to the destination node, and in the case of mass movement, it can also result in a methodological 'super-congestion' within the whole area around the destination point. In consequence, this generates an unclear picture of vehicle travel time, which differs greatly from theoretical travel time (determined on the basis of the maximum allowable speed) and is practically never observed in real life. There are, however, several approaches to eliminate this. Firstly, instead of setting a centroid as the starting and destination point of a given trip, one may apply several points within a given transport region, which should be deployed in a geometrically even manner, and their number should be determined on the basis of the total area of the administrative unit in question. Another way to avoid the methodological impasse is to develop 'artificial' starting point and destination nodes, at spots where boundaries of administrative units cross, and to simulate traffic that would start and/or finish within them. A variant of this method - slightly more efficient in imaging how units are managed - is the use of a predefined buffer of the centroid within a given administrative unit to create 'artificial' nodes. The third solution is the application of the principle that roads around the centroid towards which traffic is flowing (or which is the starting point) offer unlimited capacity (the assumption that there is no possibility of congestion on the roads directly adjacent to the node that determines the destination point - connectors).

In the subject literature, there is no consensus regarding the method of calculating travel time. Various authors - depending on the size of the analysed area and the scale of the study - adopt different methods of calculating travel time for public (Bielecka, Filipczak 2010) and individual transport. These methods may include research based on an assumed length of travel time - calculated with regard to the regulations within the Traffic Code (Wiśniewski 2014), an indirect (and thus somewhat subjective) measurement performed by a researcher who participates in the process of travelling along any given road network (Bartosiewicz, Pielesiak 2012), more advanced models - which include allowed speed limits, the lay of the land around the researched roads and the number of residents in their vicinity (Komornicki et. al. 2009), traffic density, etc. (Akcelik 1988), as well as other models, based on real-time traffic data (Wiśniewski 2015). All these are aimed at capturing, in the most plausible manner, something 'elusive', i.e. a set of individualised behaviours - different due to various traits shown by car users (e.g. temper, inclination 
Table 2 - Road capacity within the model

\begin{tabular}{lcc}
\hline Class & Cross section & Capacity [veh/h] \\
\hline motorway & $2 \times 2$ & $3,800-3,600$ \\
expressway & $2 \times 2$ & $3,500-3,300$ \\
main road of accelerated traffic & $2 \times 2$ & $1,800-1,500$ \\
main road & $2 \times 2$ & $1,300-1,100$ \\
& $1 \times 2$ & $900-700$ \\
collector road & $2 \times 2$ & $1,000-800$ \\
& $1 \times 2$ & $600-500$ \\
local road & $1 \times 2$ & $400-300$ \\
\hline
\end{tabular}

Note: motorway - a first-class controlled-access road designed exclusively for high-speed vehicular traffic, which does not serve traffic from adjacent areas; expressway - a public road of limited accessibility, designed exclusively for vehicular traffic, with mainly grade-separated junctions with other roads crossing its course; main road of accelerated traffic - the roads representing this class can have a national or (exceptionally) regional status; maximum allowable speeds in built-up areas are 60 and $70 \mathrm{~km} / \mathrm{h}$, and $60,70,80$ and $100 \mathrm{~km} / \mathrm{h}$ outside built-up areas; main road - the roads representing this class can have a national, regional, district and municipal status; maximum allowable speeds in built-up areas are 50 and $60 \mathrm{~km} / \mathrm{h}$, and 50,60 and $70 \mathrm{~km} / \mathrm{h}$ outside built-up areas; collector road - the roads representing this class can have a regional, district, and (exceptionally) municipal status; maximum allowable speeds in built-up areas are 40,50 and $60 \mathrm{~km} / \mathrm{h}$, and 40,50 , and $60 \mathrm{~km} / \mathrm{h}$ outside built-up areas; local road - the roads representing this class can have (exceptionally) a district and municipal status; maximum allowable speeds in built-up areas are 30 and $40 \mathrm{~km} / \mathrm{h}$, and 40 and $50 \mathrm{~km} / \mathrm{h}$ outside built-up areas (Rozporządzenie Ministra Transportu 1999). Source: authors' own elaboration.

for breaking the traffic code, and especially, speed limits, etc.) - presented against the background of car features (e.g. their age, technical condition, acceleration and maximum speed), the road network (e.g. its collisionality and capacity), and the remaining elements of the transport system (e.g. different traffic density at different time periods and the structure of vehicle types).

Into the application, the researcher enters csv files which contain data on nodes and edges of the road network that the researcher is about to analyse (Table 2). Next, the strategy of designating the weight of individual edges (sections of the road network) is determined by means of the available options and settings. All edges are described through the parameters that characterise them - e.g., travel time, technical condition, travel cost - and these can be used to determine their weight. In order to calculate the level of load for individual elements of the network, the software groups vehicles into abstract objects called transport packages. The operation of the application is based on a turn mechanism, where each turn lasts for a precisely stipulated length of time, during which transport packages are moved along designated routes within the network. The final input parameter to be entered by the researcher is the duration of individual turns (time intervals). Once all input parameters have been entered, several auxiliary objects are generated, the most crucial of which are Weight Strategy and Path Calculator. On the basis of the data from the provided csv files, and in accordance with the 
designated specifications, the application creates transport packages, establishes their position at the starting nodes and calculates the shortest (according to the initial guidelines) path to the destination node (these calculations are performed on the unburdened network, which guarantees that the route the package has to travel is the shortest).

Simulations begin once all the packages have been generated and located within the network. From the list of all available transport packages, the system selects those which have not reached their destination yet and have already exceeded expected arrival time (since each node can determine the time after which the packages that start there should begin moving, it is possible to conduct a simulation in which new nodes join the network with time). The packages that have reached their destinations are transferred onto a separate list and do not participate in further calculations. A file containing a turn report is generated with the data on the load of individual nodes and edges of the network.

After making an attempt to move all the packages, one ought to verify whether the first and the second collection of blocked packages have the same sizes. If the second list of blocked items is smaller than the first one (the one with which the algorithm was initiated), it means that one of the packages has moved and might have unblocked the movement of the others. If both lists are the same size, it indicates that the blocked packages have no possibility to move any further, which means that a new route to the destination point should be set for each blocked package. Once new routes have been established, one should recurrently activate for them (and only for them) the function of package movement (movement of transport packages, Point 1 of the algorithm). The implementation of Dijkstra's algorithm, which is used within the application, works on the assumption that if it is not possible to mark out a route from point $A$ to point $B$, since such a route does not exist or all roads connecting these points are blocked, the system will nominate the route as non-existent, and this will be the only case in which a transport package cannot move to the next node on its path of movement. This is aimed at designating the shortest distance between the specified node $s$ and all remaining nodes within the directed graph, when it is assumed that there are no negative-weight edges in the indegree. The algorithm remembers the set $Q$ of nodes for which the shortest paths have not been calculated, and the vector $D_{i}$ of the distance between the node $s$ and $i$. Initially, the set $Q$ contains all the nodes, and the vector $D$ is the first line of the matrix of the weights within edge $A$. While the set $Q$ remains not empty, the algorithm orders:

1. the node $v$ with the smallest value $D[v]$ to be derived and deleted from the set;

2. the relaxation of the path for each successor $i$ of the node $v$.

Due to its algorithmic paradigm, this algorithm is greedy (Dijkstra 1959), and thus, it does not always return an optimal result, even if it is considered to be an accurate 
solution. A detailed description of how the application developed by the authors of this paper works can be found in the article by Borowska-Stefańska, Kowalski, Wiśniewski (2020).

In the study it was assumed that those commuting to work are the only users of the network. On the basis of the algorithms and the aforementioned parameters, it becomes possible to determine the instant at which an employee should set out in order to reach their destination at the exact hour when they are obligated to start work, which - in conjunction with the period when working hours begin makes it possible to specify the length of the period when the road network is burdened due to commuting. The said model was applied on the assumption that each employee sets out at an hour which allows them to reach their workplace at the exact time when they should start work, with the input travel time equalling a theoretical commute time (determined exclusively on the basis of the data regarding the maximum travelling speed of vehicles on roads, without taking traffic density into account).

To sum up, the application of the aforementioned algorithm makes it possible to include an allowable speed and the technical parameters of roads and their potential 'overcrowding'. On the basis of the method presented above, five simulations (variants) of the load of the road network were conducted, analysing both the value of the said load and the spatial distribution of this phenomenon. These simulations were performed with the assumption of:

- variant I - synchronous time of starting work

- variant II - two times at which work starts, divided by a period of 30 minutes

- variant III - three times at which work starts, divided by 30 -minute periods

- variant IV - two times at which work starts, divided by a period of 60 minutes

- variant $\mathrm{V}$ - three times at which work starts, divided by 60-minute periods.

In the first variant, a general rate of motorised employees was taken, whereas in the remaining variants it was assumed that it is divided proportionally to the number of turns (times at which work starts).Variant I was taken as a reference point when analysing the changes presented in for the network load in the other variants. What is more, a theoretical commute time to work was also taken into account as the reference. The comparison of other variants with Variant I is aimed at showing to what extent changes of travel times and spatial diversification of road network load depend on the number of turns and temporal distances between them. This allows us to indicate whether the diversification of hours at which people start work has any impact on the reduction of congestion, and thus, on the shortening of travel time. 


\section{Results}

As is shown by the results of the simulation of synchronous commuting, the highest related road load will be present mainly on the roads that form a concentric layout from the city centre of Łódź. This stems from the fact that the greatest number of workplaces are located in Łódź and its immediate vicinity, and the main transport network takes the form which - with some exceptions - reflects

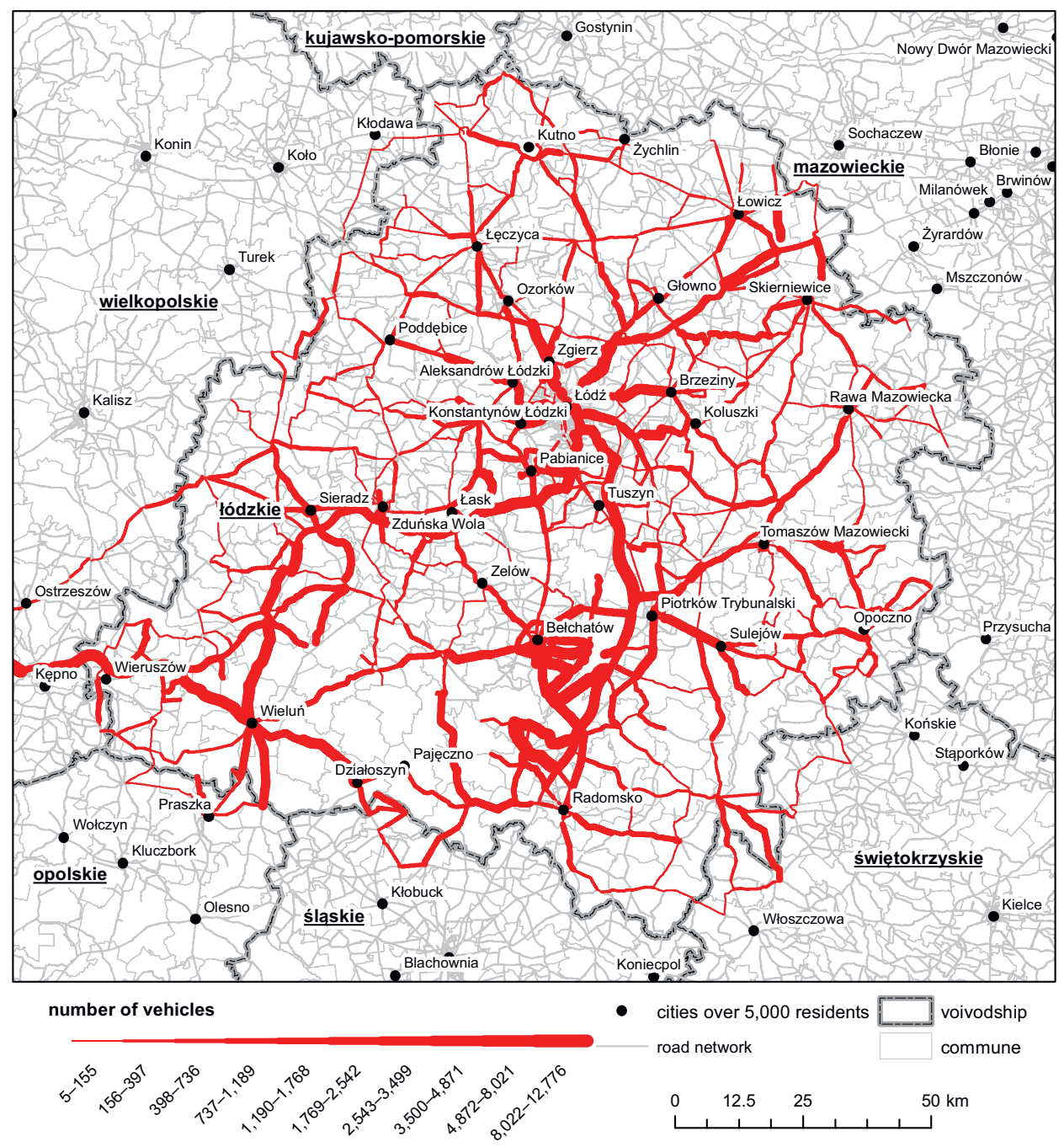

Fig. 6 - Road load related to commuting to work in the Łódź Voivodeship (variant I - synchronous trips). Source: authors' own elaboration. 
Fig. 7 - Share of total vehicle traffic related to commuting to work in the Łódź Voivodeship by road classes (synchronous trips). Source: authors' own elaboration.

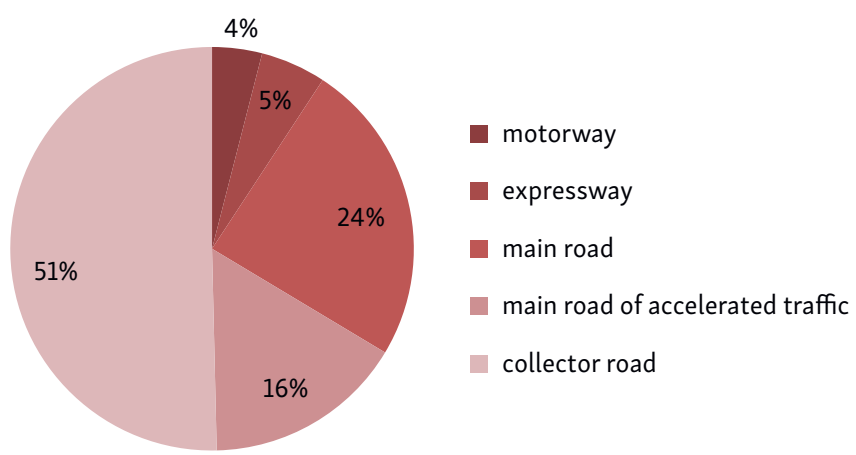

the shape of the regional workplace distribution. What is more, high traffic density is also recorded in two southern parts of the voivodeship: the Piotrków-Bełchatów Industrial Zone (Piotrkowsko-Bełchatowski Okręg Przemysłowy, P-BOP) and the Wielun Land (Fig. 6). While traffic density in the central part of the region is definitely dependent on journeys which end within the Łódź Metropolitan Area (Łódzki Obszar Metropolitalny, ŁOM), high traffic density in the area of Wielun and the Piotrków-Bełchatów Industrial Zone is, to a significant extent, generated by transit traffic heading for places other than the aforementioned regions of the voivodeship.

As far as commuting in the Łódź region is concerned, the key roles - on a macro scale (Fig. 6) - are played by trunk roads: the Wieruszów-Rzgów section of the S8, the segment of the Al between Piotrków Trybunalski and the Brójce interchange, national road numbers 45 (Wieluń area), 74 (especially around Wieluń and Bełchatów), and 48 (near Tomaszów Mazowiecki) and the 91 road between Ozorków and Łódź, which - prior to the "Big Push" period (Rosik, Stępniak, Komornicki 2015) - was the main link between north and south on a national scale. Apart from the aforementioned arteries, voivodeship roads which connect communes located in the outlying areas of the region and outside the road network, are of particular importance in the context of regional employee flows. In the central part of the region, due to the greater scale of travel, a crucial role is also played by district roads, which function as collector arteries. When analysing traffic density across the road classes (from collector ones up) and commuter trips, it must be noted that it is collector roads that are used most effectively in the region (Fig. 7 The percentage of vehicular traffic related to commuting to work for individual road classes). And this stems from the fact that, firstly, these roads are often main connections between communes, and secondly, they also play the role of roads linking communes to networks of higher-class roads.

The relatively low percentage of expressways (5.24\%) and motorways (4\%) used by commuters within the total of the road segments reveals that their routing is designed more for national and European-scale transit (which does not always 


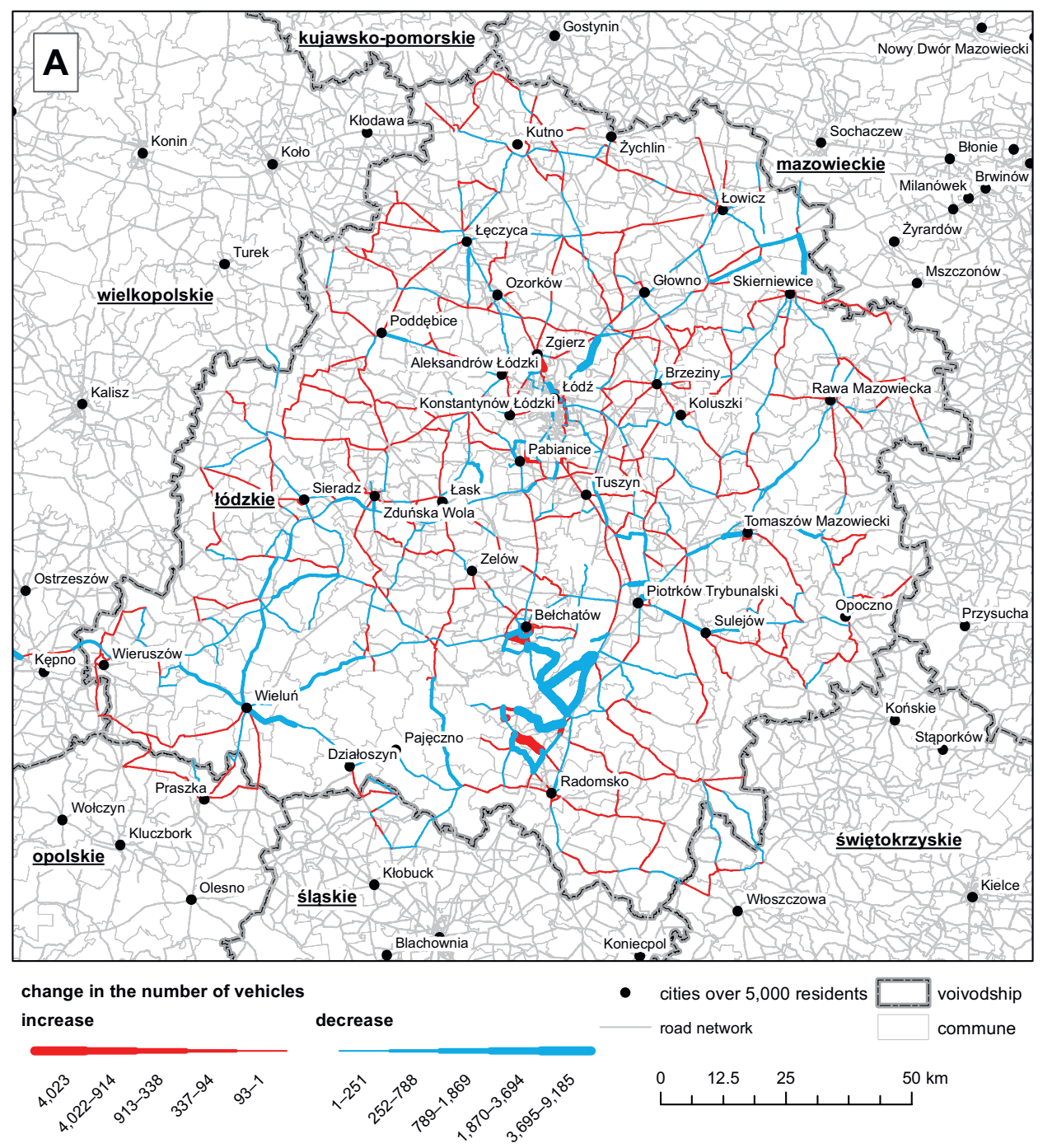

Fig. 8A - Differences in the load of the road network, resulting from the application of variant II (A), variant III (B), variant IV (C), and variant V (D) in comparison to Variant I (in which employees reach their workplaces at the same hour). Source: authors' own elaboration.

coincide with the distribution of workplaces and homes within the region) than the network of towns and settlements. An exception that proves the rule is the Wieruszów-Rzgów section of the S8 expressway, whose final course differs from the initially chosen one (through Łódź, not Piotrków Trybunalski). Its route was changed due to pressure exerted by regional and local communities - through various social movements, the mass media and intensified lobbying exercised by 


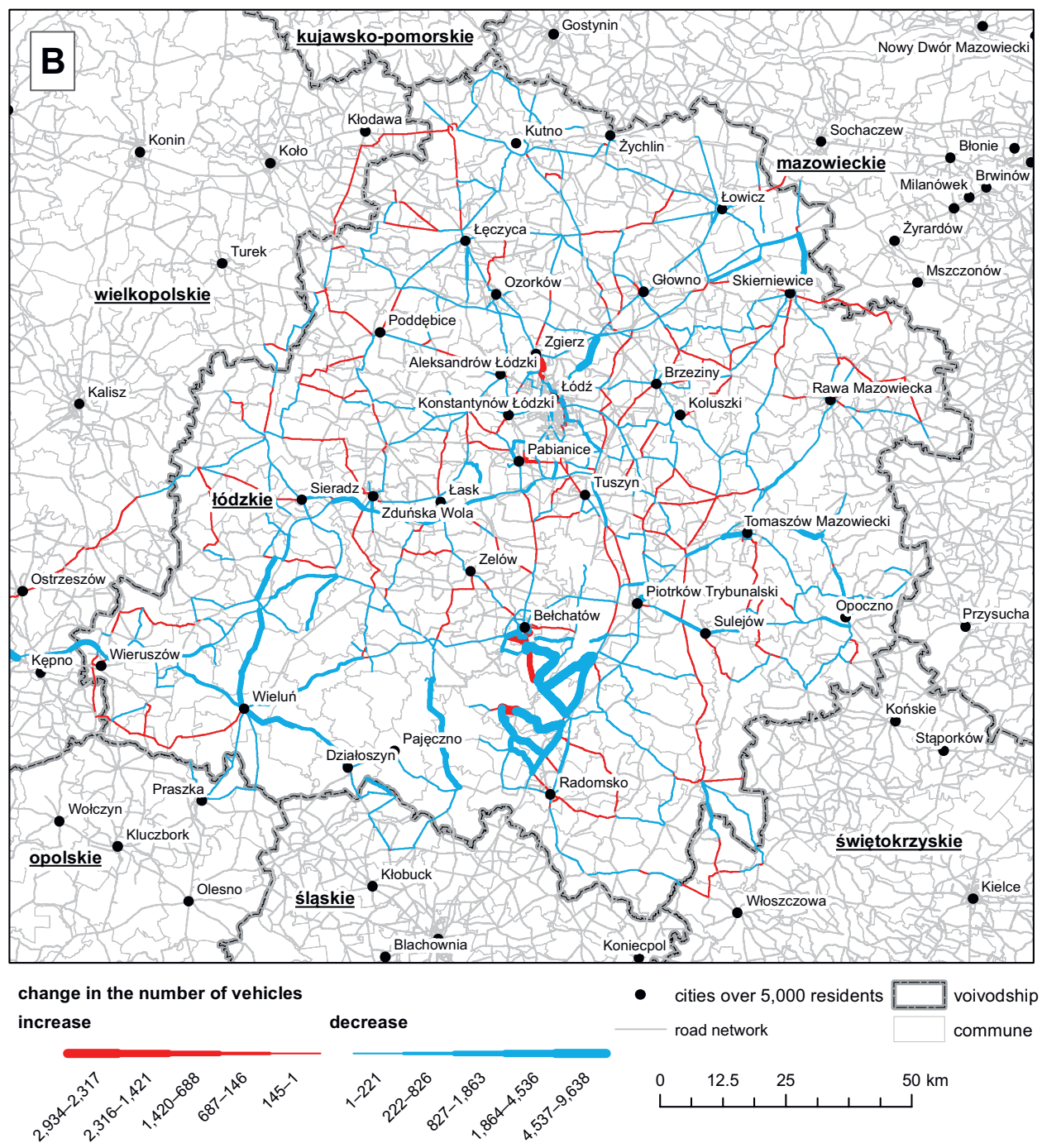

Fig. 8B - Differences in the load of the road network, resulting from the application of variant II (A), variant III (B), variant IV (C), and variant V (D) in comparison to Variant I (in which employees reach their workplaces at the same hour). Source: authors' own elaboration.

members of local governing bodies (Kozłowski, Tomczyk 2009), with the result that this expressway's role in channelling commuter traffic within the region is now significant, and this road - to a great extent - facilitates the daily commute within the region.

When half of the employees start work with a 30-minute time difference, some noticeable changes occur in the load of individual road sections within the region 


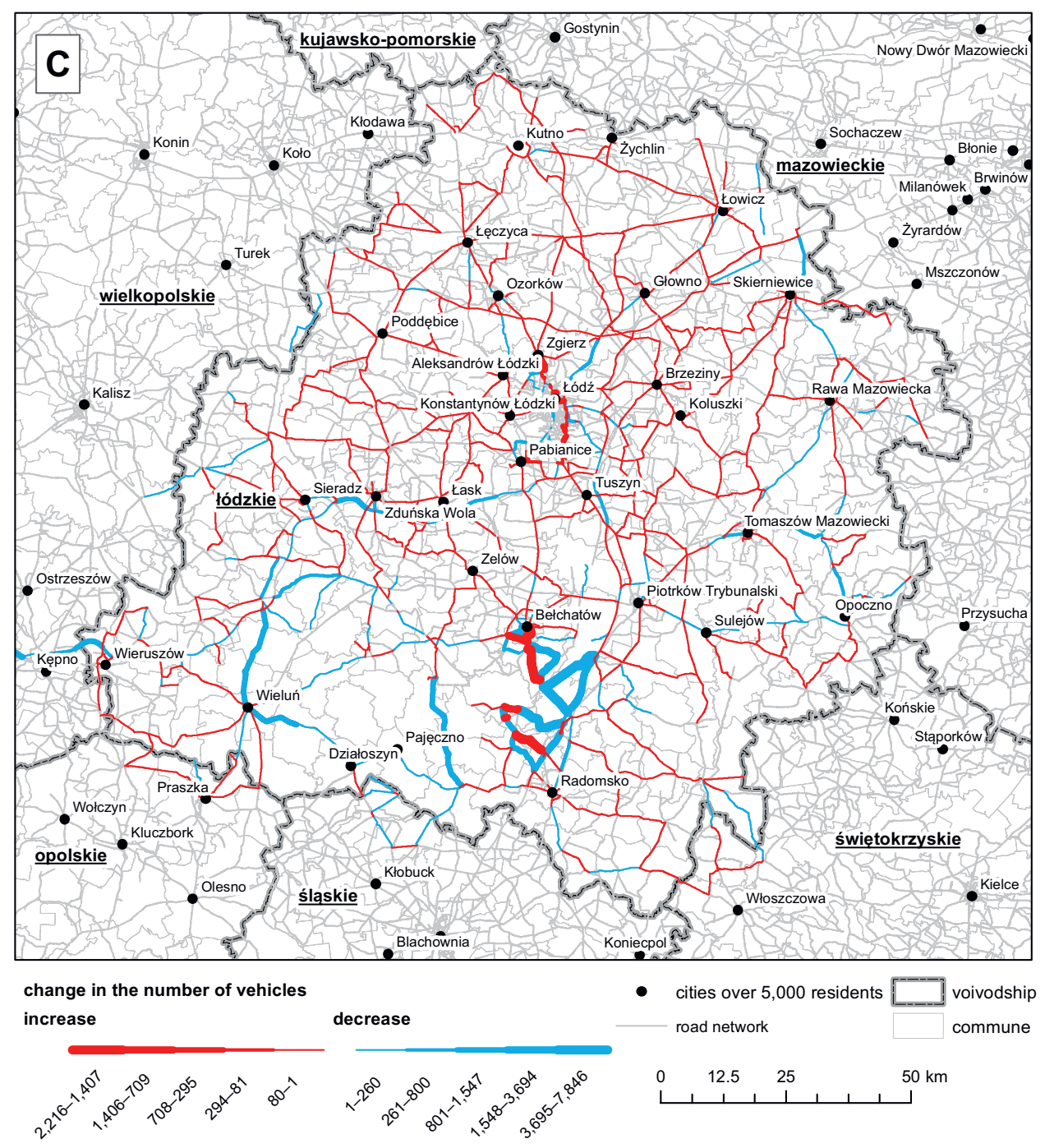

Fig. 8C - Differences in the load of the road network, resulting from the application of variant II (A), variant III (B), variant IV (C), and variant V (D) in comparison to Variant I (in which employees reach their workplaces at the same hour). Source: authors' own elaboration.

(Fig. 8A, B, C, D). By and large, these changes lead to an increase in network load, which is particularly visible in the southern part of the voivodeship (especially in the Piotrków-Bełchatów Industrial Zone). This is caused by the fact that trips taken from neighbouring communes within regions characterised by a lower density of local roads will be more evenly distributed in time, and thus, a greater amount of traffic will occur on lower-class roads since they are less congested. In the regions 


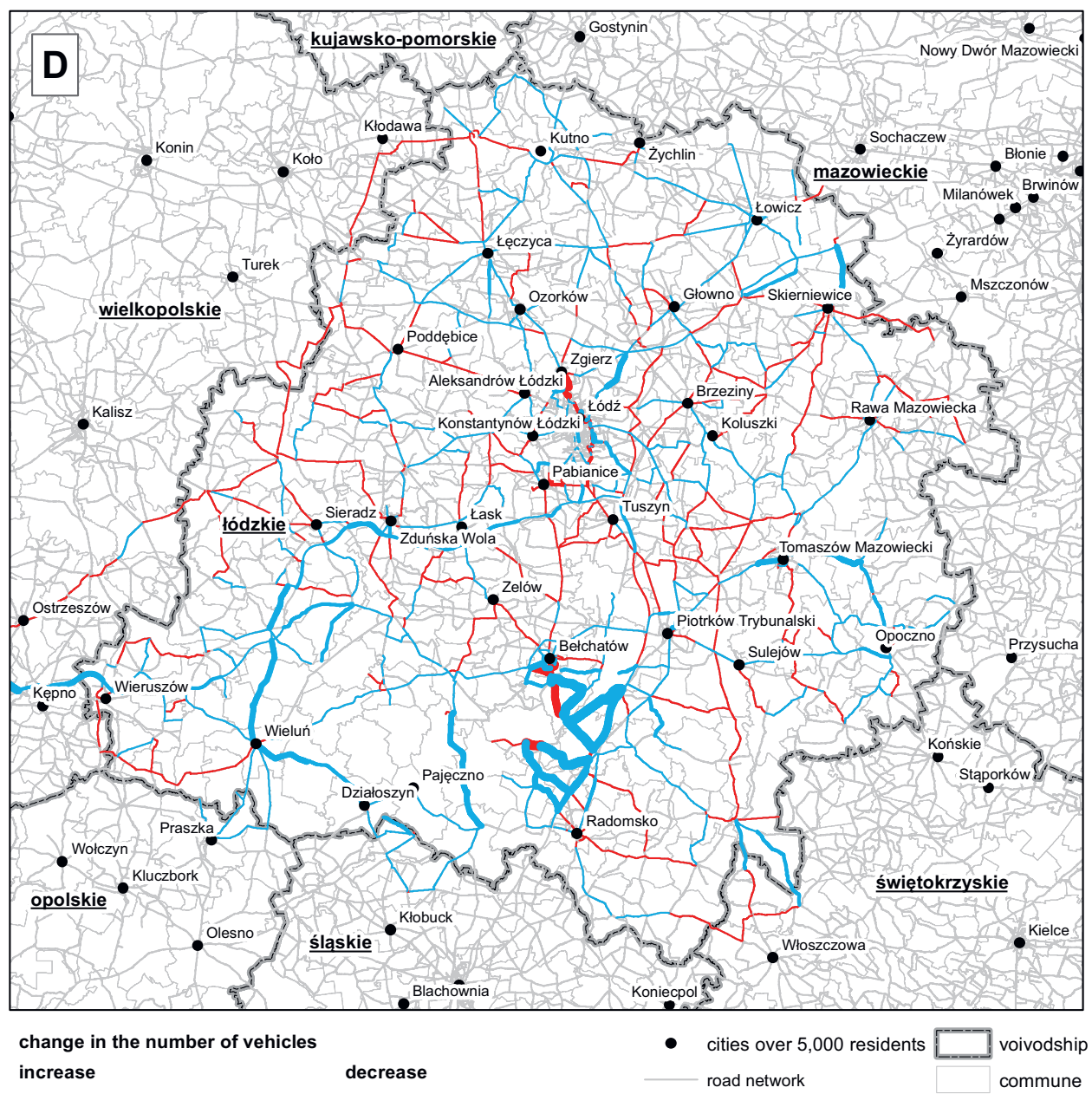

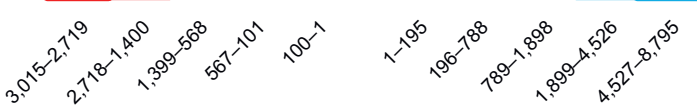

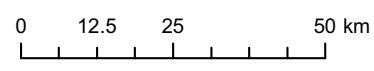

Fig. 8D - Differences in the load of the road network, resulting from the application of variant II (A), variant III (B), variant IV (C), and variant V (D) in comparison to Variant I (in which employees reach their workplaces at the same hour). Source: authors' own elaboration.

with a greater density of roads and higher overall number of trips, traffic density on collector roads will increase, stemming from the broader distribution of trips in time and smaller jams observed there, which will result in their more efficient use in comparison to the network of local roads. In variant III, the load of the network of collector and higher-class roads will decrease to an even greater extent than in the second variant. In this case, the crucial factor seems to be the increase 

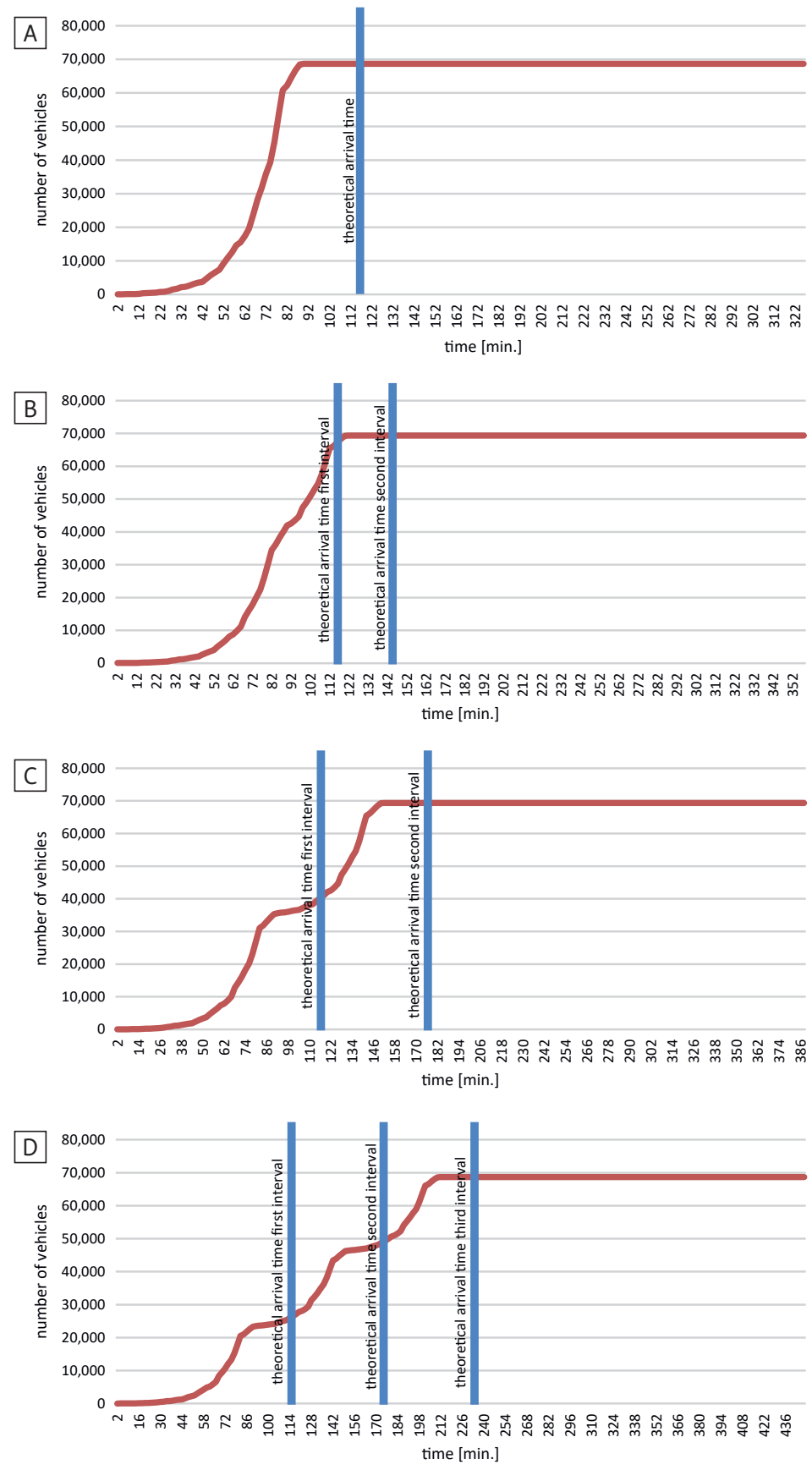

Fig. 9 - Changes in the number of commuter vehicles that are served by the regional road network, resulting from the implementation of individual commuting variants (A - Variant I; B - Variant II; C - Variant IV; D - Variant V). Source: authors' own elaboration. 
in the capacity of local roads. Similar factors influence the structure of trips in variants IV and V, where - due to a larger time interval - differences in the load of collector and higher-class roads will increase (when compared to variant I), which will result in a substantial amount of traffic being taken by local roads offering a limited capacity.

All increases and decreases in vehicle numbers, as shown in figures 7A-5D, are always in comparison to Variant I and indicate changes of traffic flows with regard to the variant in which all the commuting employees start work at the same hour.

With the assumptions applied in the model, enormous commute delays are recorded, and are similar regardless of the applied time interval. They amount to approx. 213 minutes (Fig. 9). This result seems puzzling and impossible to prove empirically, and stems from the imperfection of the model applied in the study. This imperfection fundamentally impacts the research of the period of the network load, and in the case of the study of the spatial distribution of the network, it is slight and basically negligible. It seems that the most serious methodological problem in this research is not the application of Dijkstra's algorithm and the settings related to the nature of the graph edges (road capacity and speed limits), but the manner in which the starting points and destinations were determined. In the real world, there is no such strong concentration of workplaces as assumed in the model (in one point within a commune), a concentration which leads to the development of the phenomenon called 'super-congestion' on road sections adjacent to the nearest centroid of the commune. And this 'super-congestion' is responsible for such a drastic lengthening of travel time.

Therefore, the method applied in the study necessitate an improvement due to the research limitations. Faced with the quality of the available commute data, it seems justified to make slightly different assumptions which will return marginally less objective results in terms of directions of traffic flows, but which will be significantly more effective in presenting a more accurate travel time. One of these would be the siting of starting points and destinations at the borders of administrative units (or within a certain buffer around the centroid).

\section{Conclusions}

As for the implementation of the methodological goal of the article (first of the main goals), it should be considered that the simplified assumptions from the applied research method (based on Dijkstra's algorithm and with the use of section resistance functions as established in the subject literature) stem from the quality of the available data and computing capacities. These simplifications render it impossible to fully and accurately demonstrate the phenomenon of vehicle distribution within a network up to approx. 5 minutes before the assumed finish of 
Table 3 - Time efficiency of research variants

\begin{tabular}{lrrrrr}
\hline Variant & 1 & 2 & 3 & 4 & 5 \\
\hline time interval [min] & 0 & 30 & 30 & 60 & 60 \\
number of turns & 1 & 2 & 3 & 2 & 3 \\
theoretical time of network load [min] & 115 & 145 & 175 & 175 & 235 \\
actual time of network load [time] & 328 & 360 & 418 & 386 & 448 \\
time difference of network load [min] & 213 & 215 & 243 & 211 & 213 \\
increase in time length of network load [\%] & 285.2 & 248.3 & 238.9 & 220.6 & 190.6 \\
\hline
\end{tabular}

Source: authors' own elaboration

the journey (stipulated on the basis of theoretical time), although, together with the software that enables its use, it produces accurate results when directions of traffic flows are analysed (Table 3).

The main research purpose (second of the main goals), i.e., the determination of how the phenomenon of commuting impacts the load on the road network (including from the spatial perspective) and travel times, has only been accomplished partially, due to the application of the aforementioned method. The main conclusions drawn from the study indicate:

- a significant load on higher-class roads (from collector ones up) in the central region of the voivodeship and in the vicinity of the Piotrków-Bełchatów Industrial Zone and Wieluń

- the dominance of collector roads in servicing commuter traffic

- maladjustment - to a greater extent - of the route of the network of express and motorways to the intraregional needs in terms of employee flows in the Łódź region (with the exception of the section of the S8 expressway, the routing of which was influenced by local and regional communities)

- unloading of the network of higher-class roads when hours of starting work are staggered

- the differentiation of the impact that the density of the network of lower-class roads has on the unloading recorded on main roads.

As far as intraregional employee flow is concerned, it seems imperative to implement changes to the hours of starting and finishing work, as this should contribute to a decrease in the general load of the network of main roads and also to the significant unloading of the whole road network over time.

Intuitively, one may expect that the implementation of staggered starting times will affect the functioning of the whole transport system. It is important, however, to determine the scale of this impact and its spatial distribution. As seen from the study, the total change to the road network load (including the frequency at which individual network sections become overloaded in terms of capacity) depends on 
both the number of turns during which trips are taken and the temporal intervals between them. An exceptionally crucial variable is also the potential of a given centre as workplace and its location in relation to other centres and within the transport network as a whole. It is the combination of all these variables that can tell us how great an impact commuter trips in a given region have, and whether it is justified to introduce any changes with the intention of increasing its temporal effect on journeys. The presented study proves that it is possible to model changes of travel time and road network load with regard to differentiation of working hours. It also recommends the algorithm for such research and the set of source data necessary to conduct it. Nevertheless, it is impossible (at least at this stage of research) to determine any universal relationships between shortening of travel time, lowering congestion and changes implemented for when employees start work. The conducted study also shows considerable applicational potential in terms of creating transport policies for finding a solution to the transport problems which appear whenever the capacity and quality of the road infrastructure is inadequate to the demand during peak hours (in regard to both standard commuting to work or school and irregular journeys, e.g., to mass gatherings, sporting events, etc.). The implementation of the simulations in this paper, both in reference to recurring and exceptional changes, could result in an increase in freer movement and in a faster recovery of the transport system. Since local authorities have little influence on the times at which employees are expected to start work (except for city halls and associated offices), they can only conduct informative and promotional campaigns on the matter. There are, however, certain mass events that are organised in co-operation with local authorities, and traffic simulations for such gatherings may, for instance, prevent the cumulation of traffic from employees returning from work and spectators heading for a specific public event.

\section{References}

AKCELIK, R. (1988): The highway capacity manual delay formula for signalized intersections. ITE Journal, 58, 3, 23-27.

ARNOTT, R., DE PALMA, A., LINDSEY R. (1990): Departure time and route choice for the morning commute. Transp Res Part B 24, 3, 209-228, https://doi.org/10.1016/0191-2615(90)90018-T.

ARNOTT, R., RAVE, T., SCHÖB, R. (2005): Alleviating urban traffic congestion. MIT Press, Cambidge.

BALMER, M., MEISTER, K., RIESER, M., NAGEL, K., AXHAUSEN, K.W. (2008): Agent-based simulation of travel demand: Structure and computational performance of MATSim-T', in 2nd TRB Conference on Innovations in Travel Modeling. Portland.

BARTOSIEWICZ, B. (2012): Powiązania społeczne w Łódzkim Obszarze Metropolitalnym. In: Bartosiewicz, B., Marszał, T., (eds): Spójność terytorialna Łódzkiego Obszaru Metropolitalnego, Studia KPZK PAN, 147, 83-101. 
BARTOSIEWICZ, B., PIELESIAK, I. (2012): Powiązania transportowe w Łódzkim Obszarze Metropolitalny. In: Bartosiewicz, B., Marszał, T., (eds): Spójność terytorialna Łódzkiego Obszaru Metropolitalnego, Studia KPZK PAN, 147, 105-137.

BARTUŠKA, L., ČEJKA, J., CAHA, Z. (2015): The Application of Mathematical Methods to the Determination of Transport Flows, Naše more, 62, 3, 91-96, doi: 10.17818/NM/2015/SI1.

BECKMANN, J. (2004): Mobility and safety. Theory, culture \& society, 21, 4-5, 81-100, doi: https://doi.org/10.1177/0263276404046062.

BIELECKA, E., FILIPCZAK, A. (2010): Zasady opracowywania map dostępności. Roczniki Geomatyki-Annals of Geomatics, 8, 6, 42, 29-38.

BÍLÝ, J., FIEDLER, M., NOŽIČKA, F. (1958): Die Graphentheorie in Anwendung auf das Transportproblem, Czechoslovak Mathematical Journal, 8, 1, 94-121.

BODINO, G.A. (1962): Economic applications of the theory of graphs. Routledge.

BOLLEN, K.A. (2000): Modeling Strategies: In Search of the Holy Grail, Structural Equation Modeling, 7, 1, 74-81, https://doi.org/10.1207/S15328007SEM0701.

BOROWSKA-STEFAŃSKA, M., DOMAGALSKI, A., WIŚNIEWSKI, S. (2018): Changes concerning commute traffic distribution on a road network following the occurrence of a natural disaster - The example of a flood in the Mazovian Voivodeship (Eastern Poland), Transportation Research Part D, 65, 116-137, https://doi.org/10.1016/j.trd.2018.08.008.

BOROWSKA-STEFAŃSKA, M., KOWALSKI, M., WIŚNIEWSKI, S. (2020): The use of the RoadLoad application in geographical studies of flows generated by individual modes of transport. In review.

CERVERO, R. (2006): Alternative Approaches to Modeling the Travel-Demand Impacts of Smart Growth. Journal of the American Planning Association, 72, 3, 285-295, https://doi. org/10.1080/01944360608976751.

CSO (2015): The Pilot Study on People's Travel Behaviour in Poland (2015). Central Statistical Office, https://stat.gov.pl/files/gfx/portalinformacyjny/pl/defaultstronaopisowa/5851/1/1/ raport_koncowy_badanie_pilotazowe_zachowan_komunikacyjnych.pdf (15.7.2019).

COULTER, R., HAM, M.V., FINDLAY, A.M. (2016): Re-thinking residential mobility: Linking lives through time and space. Progress in Human Geography, 40, 3, 352-374, https://doi. org/10.1177/0309132515575417.

DAGANZO, C.F. (1985): The uniqueness of a time-dependent equilibrium distribution of arrivals at a single bottleneck, Transportation science. INFORMS, 19, 1, 29-37.

DAGANZO, C.F., SHEFFI, Y. (1977): On Stochastic Models of Traffic Assignment, Transportation Science, 11, 3, 253-274, doi: https://doi.org/10.1287/trsc.11.3.253.

DE PALMA, A., LINDSEY, R. (2002): Comparison of morning and evening commutes in the Vickrey bottleneck model. Transportation Research Record: Journal of the Transportation Research Board, 1807, 26-33, https://doi.org/10.3141/1807-04.

DE PALMA, A., LINDSEY, R. (2004): Congestion pricing with heterogeneous travelers: a general-equilibrium welfare analysis. Netw Spat Econ 4, 2, 135-160, https://doi.org/10.1023/ B:NETS.0000027770.27906.82.

DERRIBLE, S., KENNEDY, C. (2011): Applications of graph theory and network science to transit network design, Transport Reviews, 31, 4, 495-519, https://doi.org/10.1080/014416 47.2010.543709.

DIJKSTRA, E.W. (1959): A note on two problems in connexion with graphs. Numerische mathematik, 1, 1, 269-271.

Eurostat regional Yearbook 2018 edition. Luxembourg 2018. 
FORD, JR., L.R., FULKERSON, D.R. (1956): Solving the Transportation Problem. Management Science, 3, 1, 24-33, https://doi.org/10.1287/mnsc.3.1.24.

FRATAR, T.J. (1954): Vehicular trip distribution by successive approximations, Traffic Quarterly, $8,53-65$.

GARRISON, W.L. (1960): Connectivity of the interstate highway system, Papers in Regional Science. Wiley Online Library, 6, 1, 121-137.

GONZALES, E.J., DAGANZO, C.F. (2012): Morning commute with competing modes and distributed demand: User equilibrium, system optimum, and pricing. Transportation Research Part B: Methodological, 46, 10, 1519-1534, https://doi.org/10.1016/j.trb.2012.07.009.

GONZALES, E.J., DAGANZO, C.F. (2013): The evening commute with cars and transit: Duality results and user equilibrium for the combined morning and evening peaks. Procedia-Social and Behavioral Sciences, 80, 249-265, https://doi.org/10.1016/j.trb.2013.06.009.

GOULD, P.R. (1967): On the geographical interpretation of eigenvalues, Transactions of the Institute of British Geographers. JSTOR, 53-86.

Polish Central Statistical Office (2016): Główny Urząd Statystyczny, http://www.stat.gov.pl (14.7.2019).

GUZIK, R. (2015): Dojazdy do pracy w województwie małopolskim 2006-2011. Wojewódzki Urząd Pracy w Krakowie, Kraków.

HAN, S., HEYDECKER, B.G. (2006): Consistent objectives and solution of dynamic user equilibrium models, Transportation Research Part B: Methodological, 40, 1, 16-34, https://doi. org/10.1016/j.trb.2005.01.002.

HAYDUK, L.A., GLASER, D.N. (2000): Jiving the Four-Step. Waltzing Around Factor Analysis, and Other Serious Fun. Structural Equation Modeling, 7, 1, 1-31, https://doi.org/10.1207/ S15328007SEM0701.

HENDRICKSON, C, KOCUR, G. (1981): Schedule delay and departure time decisions in a deterministic model. Transp Sci, 15, 1, 62-77, https://doi.org/10.1287/trsc.15.1.62.

HORNI, A., NAGEL, K., AXHAUSEN, K.W. (2016): The Multi-Agent Transport Simulation MATSim. London: Ubiquity Press.

JIA, Z., WANG, D.Z., CAI, X. (2016): Traffic managements for household travels in congested morning commute. Transportation research part E: logistics and transportation review, 91, 173-189.

JUNG, W., WANG, F., STANLEY, H.E. (2008): Gravity model in the Korean highway, Europhysics Letters, 81, 4, 1-13, https://doi.org/10.1209/0295-5075/81/48005.

KOMORNICKI, T., ŚLESZYŃSKI, P., ROSIK, P., POMIANOWSKI, W., STĘPNIAK, M., SIŁKA, P. (2009): Dostępność przestrzenna jako przesłanka kształtowania polskiej polityki transportowej, Biuletyn KPZK PAN, 241, Warsaw.

KOZŁOWSKI, R., TOMCZYK, I. (2009): Problematyka budowy dróg w Polsce na przykładzie drogi ekspresowej S-8 w województwie łódzkim, Łódź-Sieradz.

KRAFT, S. (2014): Daily spatial mobility and transport behaviour in the Czech Republic: pilot study in the Písek and Bystřice and Pernštejnem regions. Human Geographies, 8, 2, 51, https://doi.org/10.5719/hgeo.2014.82.51.

KRYWULT-ALBAŃSKA, M. (2012): Spis powszechny jako źródło informacji o ludności. Studia Socjologiczne, 4, 207, 87-107.

KWON, J., MAUCH, M., VARAIYA, P. (2006): Components of congestion: Delay from incidents, special events, lane closures, weather, potential ramp metering gain, and excess demand. Transportation Research Record: Journal of the Transportation Research Board, 1959, 84-91, https://doi.org/10.3141/1959-10. 
LAMOTTE, R., GEROLIMINIS, N. (2018): The morning commute in urban areas with heterogeneous trip lengths, Transportation Research Part B: Methodological, 117, 794-810, https:// doi.org/10.1016/j.trb.2017.08.023.

LINNEKER, B., SPENCE, N. (1996): Road transport infrastructure and regional economic development: The regional development effects of the M25 London orbital motorway. Journal of Transport Geography, 4, 2, 77-92, https://doi.org/10.1016/0966-6923(96)00001-4.

LIU, Y., LI, Y., HU, L. (2018): Departure time and route choices in bottleneck equilibrium under risk and ambiguity, Transportation Research Part B: Methodological, 117, 774-793, https:// doi.org/10.1016/j.trb.2017.09.007.

LIU, Y., NIE, Y.M. (2011): Morning commute problem considering route choice, user heterogeneity and alternative system optima. Transportation Research Part B: Methodological, 45, 4, 619-642, https://doi.org/10.1016/j.trb.2010.11.003.

MAUSS, D., JARCZOK, M.N., FISCHER, J.E. (2016): Daily commuting to work is not associated with variables of health. Journal of Occupational Medicine and Toxicology, 11, 1, 12, https:// doi.org/10.1186/s12995-016-0103-z.

MAYERES, I., OCHLEN, S., PROOST, S. (1996): The marginal external costs of urban transport. Transportation Research Part D: Transport and Environment, 1, 2, 111-130, https://doi. org/10.1016/S1361-9209(96)00006-5.

MCNALLY, M.G. (2000): The Four Step Model. In: Hensher, D.A., Button, K.J. (eds): Handbook of Transport Modelling. Pergamon, Oxford, 35-52.

MILLER, J., HOROWITZ, E. (2007): FreeSim - A Free Real-Time Freeway Traffic Simulator, Intelligent Transportation Systems Conference. IEEE, Seattle, 18-23, https://doi.org/10.1109/ ITSC.2007.4357627.

NOLAND, R.B., SMALL, K.A. (1995): Travel-time uncertainty, departure time choice, and the cost of the morning commute. Institute of Transportation Studies, University of California, Irvine.

NOSAL, K. (2011): Mobility management concept and examples of its usage in Polish conditions. Transport Problems, 6, 4, 13-22.

NYSTUEN, J.D., DACEY, M.F. (1961): A graph theory interpretation of nodal regions', Papers of the Regional Science Association, 7, 1, 29-42, https://doi.org/10.1007/BF01969070.

OGUNSANYA, A., ADE, B. (1986): Graph theory in intra-urban traffic flow estimation, GeoJournal, 12, 3, 334-336.

OLABARRIA, M., PÉREZ, K., SANTAMARIÑA-RUBIO, E., ARAGAY, J.M., CAPDET, M., PEIRÓ, R., BORRELL, C. (2013): Work, family and daily mobility: a new approach to the problem through a mobility survey. Gaceta sanitaria, 27, 5, 433-439, https://doi.org/10.1016/j. gaceta.2012.08.008.

OPOCZYŃSKI, K. (2016): Synteza wyników GPR 2015 na zamiejskiej sieci dróg krajowych. Generalna Dyrekcja Dróg Krajowych i Autostrad.

PALMGREN, F., BERKOWICZ, R., ZIV, A., HERTEL, O. (1999): Actual car fleet emissions estimated from urban air quality measurements and street pollution models. Science of the Total Environment, 235, 1-3, 101-109, https://doi.org/10.1016/S0048-9697(99)00196-5.

PANECKA-NIEPSUJ, M. (2015): Przestrzenne zróżnicowanie miast średniej wielkości w Polsce wg dojazdów do pracy. Annales Universitatis Paedagogicae Cracoviensis Studia Geographica, 9, 83-95.

PARTHASARATHI, P., HOCHMAIR, H., LEVINSON, D.M. (2009): The influence of network structure on travel distance, Available at SSRN 1736326.

QIAN, Z.S., ZHANG, H.M. (2011): Modeling multi-modal morning commute in a one-to-one corridor network. Transportation Research Part C: Emerging Technologies, 19, 2, 254-269. 
RASTOGI, R. (2011): Promotion of non-motorized modes as a sustainable transportation option: policy and planning issues. Current Science, 1340-1348.

ROSIK, P., KOMORNICKI, T., GOLISZEK, S., ŚLESZYŃSKI, P., SZARATA, A., SZEJGIECKOLENDA, B., POMIANOWSKI W., KOWALCZYK, K. (2018): Kompleksowe modelowanie osobowego ruchu drogowego w Polsce: uwarunkowania na poziomie gminnym, 267, IGiPZ PAN, Warszawa.

ROSIK, P., STĘPNIAK, M., KOMORNICKI, T. (2015): The decade of the big push to roads in Poland: Impact on improvement in accessibility and territorial cohesion from a policy perspective. Transport Policy, 37, 134-146, https://doi.org/10.1016/j.tranpol.2014.10.007.

ROSIK, P., STĘPNIAK, M., WIŚNIEWSKI, R. (2010): Dojazdy do pracy do Warszawy i Białegostoku-alternatywne podejścia metodologiczne. Studia Regionalne i Lokalne, 2, 40, 77-98.

Rozporządzenie Ministra Transportu i Gospodarki Morskiej w sprawie warunków technicznych jakim powinny odpowiadać drogi publiczne i ich usytuowanie. Dz.U. z 1999 r. nr 43, poz. 430.

SCOTT, D.M., NOVAK, D.C., AULTMAN-HALL, L., GUO, F. (2006): Network robustness index: A new method for identifying critical links and evaluating the performance of transportation networks. Journal of Transport Geography, 14, 3, 215-227.

SMITH, M.J. (1984): The existence of a time-dependent equilibrium distribution of arrivals at a single bottleneck, Transportation science. INFORMS, 18, 4, 385-394.

STĘPNIAK, M., JACOBS-CRISIONI, C. (2017): Reducing the uncertainty induced by spatial aggregation in accessibility and spatial interaction applications. Journal of transport geography, 61, 17-29, https://doi.org/10.1016/j.jtrangeo.2017.04.001.

TOPP, H.H. (1993): Parking policies to reduce car traffic in German cities. Transport Reviews, 13, 1, 83-95, https://doi.org/10.1080/01441649308716836.

The Concept to Spatial Planning and Development of Poland 2030. Ministry of Regional Development, Warszaw 2012, http://www.esponontheroad.eu/dane/web_espon_library_files/682/ national_spatial_development_concept_2030_summary.pdf (16.7.2019).

VICKREY, W.S. (1969): Congestion theory and transport investment. The American Economic Review, 59, 2, 251-260.

VOORHEES, A.M. (1955): A General Theory of Traffic Movement, Procedings of the Institute of Traffic Engineers, 46-56.

WIŚNIEWSKI, S. (2014): Dostępność transportowa Uniejowa-ujęcie regionalne. Biuletyn Uniejowski, 3, 67-84.

WIŚNIEWSKI, S. (2015): Zróżnicowanie dostępności transportowej miast w województwie łódzkim. Wydawnictwo Uniwersytetu Łódzkiego, Łódź.

XIAO, F.E., QIAN, Z.S., ZHANG, H.M. (2011): The morning commute problem with coarse toll and nonidentical commuters. Networks and Spatial Economics, 11, 2, 343-369, https://doi. org/10.1007/s11067-010-9141-8

\section{ACKNOWLEDGEMENT}

The ongoing development of the software discussed in the article is financed in the framework of the project No. 2018/29/B/HS4/01020 conducted under the auspices of the Polish National Science Centre. 
ORCID

MARTA BOROWSKA-STEFAŃSKA

https://orcid.org/0000-0003-2448-4778

MICHAє KOWALSKI

https://orcid.org/0000-0001-7082-5161

SZYMON WIŚNIEWSKI

https://orcid.org/0000-0001-5488-5949 